\title{
PERBANDINGAN PENGARUH RETURN ON ASSET, PERTUMBUHAN ASET, PERTUMBUHAN PENJUALAN DAN MANAGERIAL OWNERSHIP TERHADAP STRUKTUR MODAL PERUSAHAAN MULTINASIONAL DAN DOMESTIK DI BEI
}

\author{
Murtiadi Awaluddin ${ }^{1 *}$, Khaerah Amalia ${ }^{2}$, Andi Sylvana ${ }^{3}$ dan Rulyanti Susi \\ Wardhani $^{4}$ \\ ${ }^{1}$ Program Pascasarjana, UIN Alauddin Makassar \\ ${ }^{2}$ Program Studi Manajemen, UIN Alauddin Makassar \\ ${ }^{3}$ Fakultas Ekonomi, Universitas Terbuka Jakarta \\ ${ }^{4}$ Fakultas Ekonomi, Universitas Bangka Belitung
}

\begin{abstract}
Abstrak: Penelitian ini bertujuan untuk mengetahui perbedaan yang memengaruhi struktur modal pada perusahaan manufaktur multinasional dan domestik di Bursa Efek Indonesia. Penelitian ini menggunakan metode kuantitatif dengan tahun pengamatan 2012-2016 pada 10 sampel yang terbagi menjadi masing-masing 5 perusahaan multinasional dan 5 perusahaan domestik. Hasil penelitian menunjukkan ROA, pertumbuhan penjualan dan managerial ownership perusahaan multinasional berpengaruh secara signifikan terhadap struktur modal. Sedangkan untuk perusahaan domestik, pertumbuhan aset, pertumbuhan penjualan dan managerial ownership berpengaruh secara signifikan terhadap struktur modal. Uji beda menunjukkan terdapat perbedaan managerial ownership dan struktur modal, dan tidak berbeda pada ROA, pertumbuhan aset dan pertumbuhan penjualan antara perusahaan multinasional dan domestik.
\end{abstract}

Kata Kunci : ROA, Pertumbuhan Aset, Pertumbuhan Penjualan, Managerial Ownership dan Struktur Modal

Abstract: This study aims to determine the differences that affect the capital structure of multinational and domestic manufacturing companies on the Indonesia Stock Exchange. This study uses a quantitative method within 2012-2016 in 10 samples divided into 5 multinational companies and 5 domestic companies. The results showed that ROA, sales growth and managerial ownership had a significant effect on capital structure in multinational companies; on the other hand, they are asset growth, sales growth, and managerial ownership for domestic companies. Difference tests show that only managerial ownership and capital structure are different, but not to ROA, asset growth and sales growth between multinational and domestic companies.

Keywords: ROA, Asset Growth, Sales Growth, Managerial Ownership, and Capital Structure

*Surel Korespondensi Penulis: murtiadi.awaluddin@uin-alauddin.ac.id

DOI: $10.24252 /$ minds.v6i1.7965

ISSN-E: 2597-6990

ISSN-P: 2442-4951

http://journal.uin-alauddin.ac.id/index.php/minds 


\section{PENDAHULUAN}

Perkembangan ekonomi di dunia semakin hari semakin pesat. Begitupun di Indonesia, perekonomian Indonesia sedang memasuki era pasar bebas yang kemudian menjadikan kegiatan ekonomi Indonesia ditopang oleh berbagai jenis industri. Secara garis besar, industri di Indonesia dijalankan oleh perusahaanperusahaan yang dibagi ke dalam dua kelompok yang mempunyai perbedaan status kepemilikan, yaitu: perusahaan milik asing yang disebut Manufacture Multinational Corporate (MNC) dan perusahaan milik domestik yang disebut Domestic Corporate (DC) (Soukotta, 2012). Perusahaan multinasional merupakan perusahaan yang terlibat dalam suatu bisnis internasional dan kepemilikan ekuitas di banyak negara. Sedangkan perusahaan domestik adalah perusahaan yang basis usahanya mencakup kegiatan ekonomi satu negara atau lingkup ekonomi nasional (Putri 2017;Handayan 2016; Maryanti 2016).

Keputusan pendanaan perusahaan dapat dilihat dari struktur modalnya. Najmuddin (2011) menyatakan bahwa struktur modal merupakan penentuan tentang proporsi tertentu dari total modal yang dibutuhkan perusahaan yang akan didanai dengan hutang dan ekuitas. Untuk sumber pendanaan perusahaan, bisa berasal dari dana internal maupun eksternal perusahaan. Sumber dana perusahaan yang berasal dari dana internal berupa laba (keuntungan) perusahaan yang belum dibagikan, sedangkan pendanaan eksternal perusahaan berasal dari investor, dengan cara mengeluarkan surat berharga, baik surat hutang maupun saham.

Salah satu sumber dana eksternal perusahaan yang sering dijadikan sebagai pertimbangan para manajer adalah hutang. Hutang menjadi salah satu sarana pendanaan yang menarik bagi perusahaan untuk rekapitalisasi atau restrukturisasi modal, karena hutang sebagai penggunaan sumber dana yang memiliki beban tetap dengan harapan akan memberikan tambahan keuntungan yang lebih besar bagi pemegang saham. Dalam lingkup trade off theory, Modigliani dan Miller menunjukkan bahwa penggunaan hutang akan selalu lebih menguntungkan daripada penggunaan modal sendiri (Brigham, Eugene F. \& Houston 2010; Husnan dan Enni 2015). Myers dan Majluf (1984) berpendapat tujuan dari trade off theory adalah menyeimbangkan modal sendiri dengan modal luar.

Rasio antara sumber dana pihak ketiga dengan hutang yang menggambarkan struktur modal perusahaan disebut DER (Debt to Equity Ratio). Rasio DER menunjukkan tingkat risiko suatu perusahaan dimana semakin tinggi rasio DER maka semakin tinggi risiko perusahaan. Menurut Brigham, Eugene F. \& Houston (2010), para investor lebih tertarik pada tingkat DER tertentu yang besaran rasionya kurang dari satu, karena nilai DER perusahaan yang menunjukkan nilai lebih dari satu memberi arti bahwa koefisien hutang dalam suatu perusahaan lebih tinggi dari jumlah modal sendiri. Koefisien hutang 
adalah angka perbandingan antara jumlah modal asing dengan modal sendiri tidak boleh melebihi 1:1. Berikut perbedaan rata-rata DER perusahaan manufaktur MNC dan DC di Indonesia:

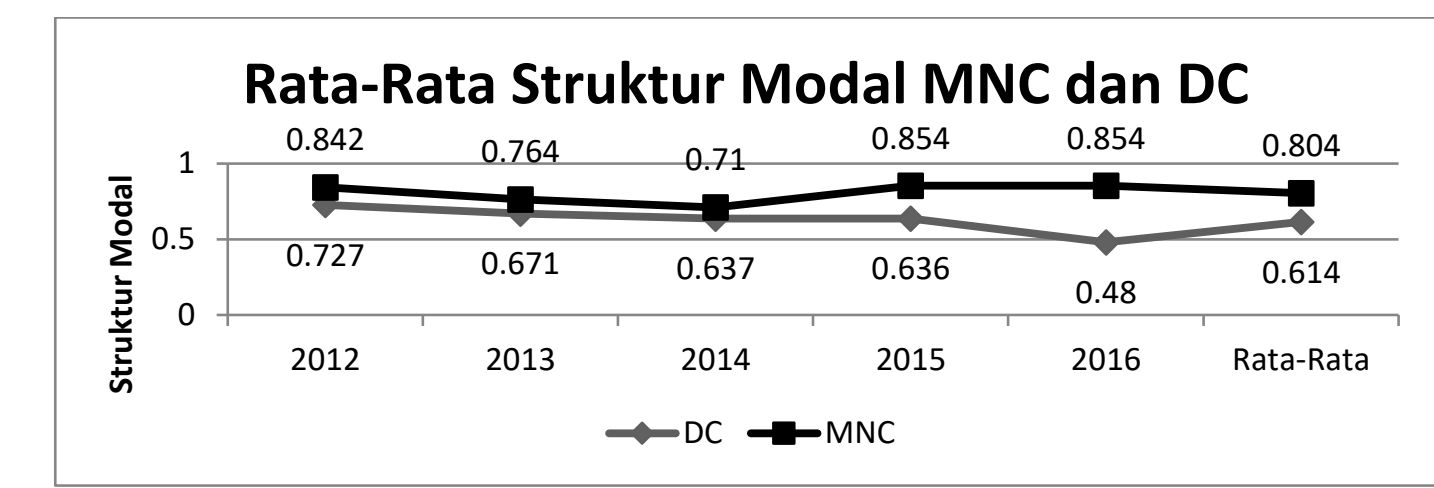

Grafik 1. Perkembangan struktur modal (DER) MNC dan DC yang terdaftar di BEI periode 20122016.

Berdasarkan tabel dan grafik di atas, menunjukkan adanya fenomena gap. Dimana, pendanaan melalui hutang yang dilakukan oleh multinational corporate lebih tinggi dibandingkan dengan domestic corporate. Hal tersebut ditunjukkan dengan nilai rata-rata DER pertahun dari tahun 2012-2016 pada multinational corporate lebih besar daripada domentic corporate. Nilai DER yang lebih besar menunjukkan bahwa perusahaan multinasional lebih banyak menggunakan hutang dari pada modal sendirinya dan ini berarti bahwa perusahaan menanggung biaya modal yang besar dan akan sebanding dengan risiko yang akan dihadapinya.

\section{TINJAUAN TEORITIS}

\section{Teori Struktur Modal}

Teori pembangun struktural modal terdiri dari Balancing Theory, Packing Order Theory, dan Trade Off Theory. Menurut Myers Balancing Theory disebut sebagai teori-teori keseimbangan, karena tujuannya adalah untuk menyeimbangkan komposisi hutang dan modal sendiri. Pembicaraan Balancing Theory dimulai dari keadaan yang ekstrem, yaitu pada kondisi pasar modal yang sempurna dan tidak ada pajak. Myers telah mengelompokkan berbagai faktor yang mempengaruhi struktur modal yaitu perusahaan yang mengikuti balance theory dan perusahaan yang mengikuti packing order theory. Mendasar pada balance theory perusahaan berupaya mempertahankan struktur modal yang ditargetkan dengan tujuan memaksimumkan nilai perusahaan (Husnan dan Enni 2015). Menurut Myers, packing order theory menyatakan bahwa: 1) Perusahaan menyukai internal financing (pendanaan dari hasil operasi perusahaan, yang berwujud laba ditahan), 2) Apabila dana dari luar (external financing) diperlukan maka perusahaan akan menerbitkan sekuritas yang paling aman terlebih dahulu, yaitu dimulai dengan menerbitkan obligasi, kemudian diikuti oleh sekuritas yang 
berkarakteristik opsi (seperti obligasi konversi), baru kemudian apabila masih belum mencukupi akan menerbitkan saham baru (Husnan dan Enni 2015; Metha Arieska dan Barbara Gunawan 2011).

Trade Off Theory yang dikemukakan oleh Myers yang mempunyai asumsi bahwa struktur modal perusahaan merupakan keseimbangan antara keuntungan penggunaan hutang dengan biaya financial distress (kesulitan keuangan) dan agency cost (biaya keagenan). Dari model ini dapat dinyatakan bahwa perusahaan yang tidak menggunakan pinjaman sama sekali dan perusahaan yang menggunakan pembiayaan investasinya dengan pinjaman seluruhnya adalah buruk. Keputusan terbaik adalah keputusan yang moderat dengan mempertimbangkan kedua instrument pembiayaan (Najmuddin, 2011;Avramov et al. 2013).

Signalling Theory

Isyarat atau signal menurut Brigham dan Houston adalah suatu tindakan yang diambil manajemen perusahaan yang memberi petunjuk bagi investor tentang bagaimana manajemen memandang prospek perusahaan. Perusahaan dengan prospek yang menguntungkan akan mencoba menghindari penjualan saham dan mengusahakan setiap modal baru yang diperlukan dengan cara-cara lain, termasuk penggunaan hutang yang melebihi terget struktur modal yang normal. Perusahaan dengan prospek yang kurang menguntungkan akan cenderung untuk menjual sahamnya (Najmuddin, 2011) (Morris 1987; Bergh et al. 2014).

\section{Agency Theory}

Teori keagenan ini muncul ketika terjadi kontrak antara manajer sebagai agen dan pemilik saham sebagai participal. Seorang manajer dikontrak oleh pemegang saham untuk bekerja demi kepentingannya. Karena mereka dipilih, maka pihak manajer harus mempertanggungjawabkan semua pekerjaannya, serta berkewajiban untuk memberikan informasi kepada pemegang saham. Sedangkan pemegang saham memberikan kepercayaan sepenuhnya kepada manajer untuk mengambil keputusan yang dapat menguntungkan baginya. Teori keagenan ini dipandang lebih luas karena teori ini dianggap lebih mencerminkan kenyataan yang ada (Najmuddin, 2011; Linder dan Foss 2015; Jensen dan Meckling 1976).

Struktur modal adalah bauran (proporsi) pendanaan jangka panjang perusahaan yang ditunjukkan oleh hutang, ekuitas, saham preferen dan saham biasa (Brigham dan Hauston, 2014). Struktur modal dapat diukur dengan menggunakan Debt to Equity Ratio (DER) yang menunjukkan tingkat risiko suatu perusahaan. Semakin tinggi rasio DER maka semakin tinggi pula risiko yang akan terjadi pada perusahaan. Hal ini dikarenakan pendanaan perusahaan dari unsur hutang lebih besar dari pada modal sendiri. Penentu struktur modal merupakan kebijakan yang diambil oleh pihak manajemen dalam rangka 
memperoleh sumber dana sehingga dapat digunakan untuk aktivitas operasional perusahaan ( Dwiyati 2011; Andriasari, Miyasto dan Mawardi 2014).

Faktor-Faktor yang Memengaruhi Struktur Modal adalah; Return on Aset (ROA), Pertumbuhan Aset, Pertumbuhan Penjualan, dan Managerial Ownership. Untuk mengukur kinerja suatu perusahaan pada umumnya digunakan analisis profitabilitas (ROA) memfokuskan kemampuan perusahaan dalam memperoleh earning dalam operasi perusahaan. Return on Asset (ROA) memberikan informasi seberapa efisien suatu perusahaan dalam melakukan kegiatan usahanya, karena rasio ini mengidentifikasi seberapa besar keuntungan yang dapat diperoleh ratarata terhadap setiap rupiah asetnya.(Marfuatun dan Indarti 2012). Kemudian Aset merupakan aktiva yang digunakan untuk aktivitas operasional perusahaan. Semakin besar aset diharapkan semakin besar hasil operasi yang dihasilkan oleh perusahaan. Pertumbuhan aset adalah perubahan (peningkatan atau penurunan) total aktiva yang dimiliki oleh perusahaan. Pertumbuhan aset dihitung sebagai persentase perubahan aset pada tahun tertentu dikurangi tahun sebelumnya (Sari dan Haryanto 2013).

Selanjutnya pertumbuhan penjualan merupakan ukuran mengenai besarnya pendapatan per saham perusahaan yang diperbesar oleh hutang. Suatu perusahaan yang berada dalam industri yang mempunyai laju pertumbuhan yang tinggi, harus menyediakan modal yang cukup untuk membelanjai perusahaan. Perusahaan yang bertumbuh pesat cenderung lebih banyak menggunakan hutang untuk membiayai kegiatan usahanya daripada perusahaan yang tumbuh secara lambat (Detiana 2011). Managerial Ownership menjadi salah satu upaya yang bisa ditempuh untuk mengurangi konflik ini. Managerial Ownership menunjukkan kepemilikan manajer atas saham di dalam sebuah perusahaan. Ini berarti seorang manajer akan berkedudukan ganda, tidak hanya sebagai seorang manajer saja tetapi juga merupakan pemegang saham. Di harapkan dengan posisinya ini, manajer bisa mengambil keputusan yang tepat bagi pihak manajemen dan pemegang saham karena tentu saja ia tidak menginginkan keputusan yang akan diambilnya tersebut merugikan posisinya, baik sebagai manajer maupun sebagai pemegang saham. Dengan demikian, konflik kepentingan antar pemilik dapat terjadi (Dwiyati, 2011). Berdasarkan teori di atas maka hipotesis penelitian ini adalah sebagai berikut:

$\mathrm{H}_{1}$ : Ada pengaruh positif dan signifikan antara ROA terhadap DER

$\mathrm{H}_{2}$ : Ada pengaruh positif dan signifikan antara pertumbuhan aset terhadap DER $\mathrm{H}_{3}$ : Ada pengaruh positif dan signifikan antara pertumbuhan penjualan terhadap DER

$\mathrm{H}_{4}$ : Ada pengaruh positif dan signifikan antara managerial ownership terhadap DER 
Multinational Corporate

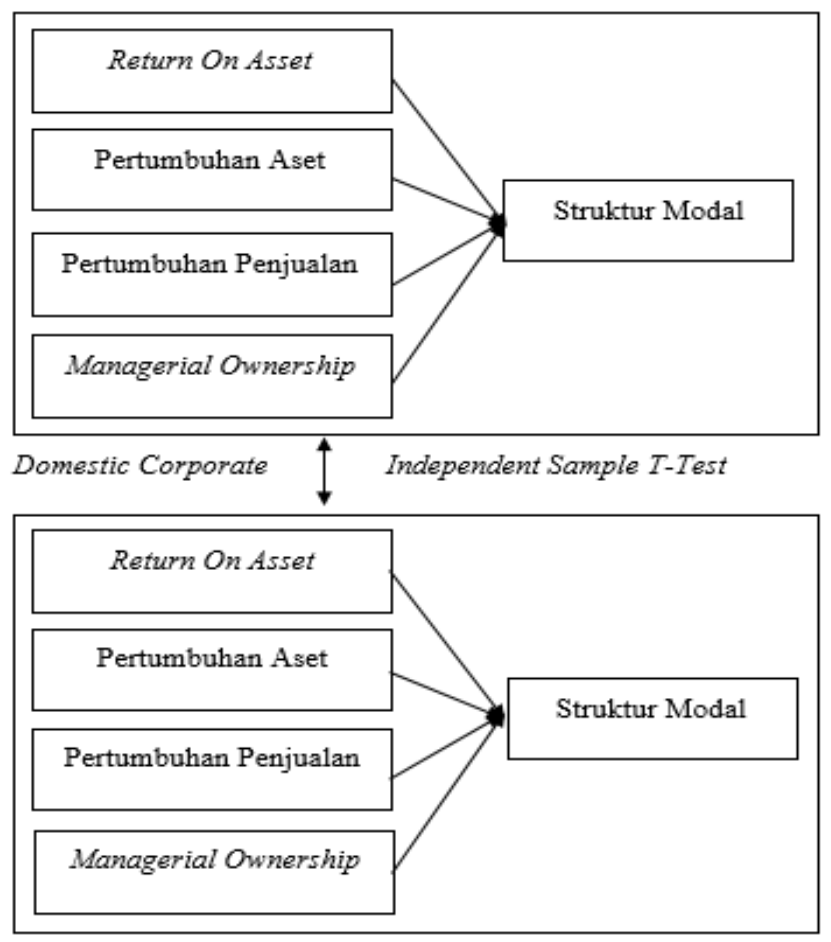

Gambar 2. Kerangka Konseptual Penelitian

Berdasarkan kerangka pikir di atas yang akan diteliti adalah pengaruh ROA, Pertumbuhan Assets, Pertumbuhan Penjualan, Managerial ownership terhadap struktur modal baik kelompok perusahaan multinasional maupun perusahaan domestik, kemudian dari hasil tersebut kemudian dilihat perbedaan diantara keduanya.

\section{METODE PENELITIAN}

Penelitian ini merupakan penelitian eksplanatory komparatif dengan menggunakan pendekatan kuantitatif. Populasi dalam penelitian ini adalah seluruh perusahaan Manufacture Multinasional Corporation dan Domestic Corporation yang terdaftar di BEI pada periode penelitian tahun 2012-2016. Penentuan sampel dalam penelitian ini adalah dengan menggunakan purposive sampling sehingga diperoleh sampel sebanyak 10 perusahaan yang masingmasing terbagi atas 5 sampel untuk perusahaan multinasional $5 \times 5$ (tahun) $=25$ data dan sebanyak 5 sampel untuk perusahaan domestik $5 \times 5$ (tahun) $=25$ data.

Teknik analisis yang digunakan dalam penelitian ini yaitu Asumsi Klasik yang terdiri atas uji normalitas, multikoliniaritas, otorokelasi dan heterokedastisitas. Berikutnya adalah Analisis Regresi Berganda dan uji beda. Uji beda yang digunakan independent sample T-Test untuk menguji perbedaan return on asset, pertumbuhan aset, pertumbuhan penjualan dan managerial ownership. 


\section{HASIL DAN PEMBAHASAN}

Analisis Statistik Deskriptif

Analisis Deskriptif pada penelitian ini digunakan untuk mendeskripsikan data-data terkait penelitian dari nilai rata-rata, standar deviasi, maksimum dan minimum.

Tabel 1 Statistik Deskriptif MNC

\begin{tabular}{|l|r|r|r|r|r|}
\hline & $\mathrm{N}$ & Minimum & Maximum & Mean & $\begin{array}{c}\text { Std. } \\
\text { Deviation }\end{array}$ \\
\hline ROA & 25 & -1.50 & .90 & .0856 & .38066 \\
\hline PA & 25 & -.11 & .57 & .1165 & .13705 \\
\hline PP & 25 & -.24 & .24 & .0742 & .10674 \\
\hline MO & 25 & .00 & .14 & .0527 & .04983 \\
\hline DER & 25 & .10 & 1.37 & .8084 & .40679 \\
\hline
\end{tabular}

Berdasarkan tabel di atas dapat diketahui bahwa ROA memiliki nilai antara 1,50-0.90 dengan nilai rata-rata (mean) sebesar 0.0856 dan standar deviasi sebesar 0.38066. sedangkan pertumbuhan aset memiliki nilai antara -0,11-0,57 dengan nilai rata-rata (mean) sebesar 0,1165 dan standar deviasi sebesar 0,13706. Adapaun pertumbuhan penjualan memiliki nilai antara -0,24-0,24 dengan nilai rata-rata (mean) sebesar 0,0742 dan standar deviasi sebesar 0,10674. Serta managerial ownership memiliki nilai antara $-0,00-0,14$ dengan nilai rata-rata (mean) sebesar 0,0527 dan standar deviasi sebesar 0,04983. Dan yang terakhir DER memiliki nilai antara 0,10-1,37 dengan nilai rata-rata (mean) sebesar 0.8084 dan standar deviasi sebesar 0.40679 .

Tabel 2 Statistik Deskriptif DC

\begin{tabular}{|l|r|r|r|r|r|}
\hline & $\mathrm{N}$ & Minimum & Maximum & Mean & $\begin{array}{c}\text { Std. } \\
\text { Deviation }\end{array}$ \\
\hline ROA & 25 & .03 & .80 & .1482 & .14853 \\
\hline PA & 25 & -.05 & .84 & .1675 & .21407 \\
\hline PP & 25 & -.08 & .42 & .1115 & .11837 \\
\hline MO & 25 & .00 & 1.00 & .2809 & .34207 \\
\hline DER & 25 & .10 & 1.45 & .6306 & .34965 \\
\hline
\end{tabular}

Berdasarkan tabel di atas dapat diketahui bahwa ROA memiliki nilai antara -0.03-0-80 dengan nilai rata-rata (mean) sebesar 0.1482 dan standar deviasi sebesar 0.14853. sedangkan pertumbuhan aset memiliki nilai antara -0,05-0.84 dengan nilai rata-rata (mean) sebesar 0.1675 dan standar deviasi sebesar 0.21407. Adapaun pertumbuhan penjualan memiliki nilai antara -0.08-0.042 dengan nilai rata-rata (mean) sebesar 0.1115 dan standar deviasi sebesar 0.11837. Serta managerial ownership memiliki nilai antara 0.00-1.00 dengan nilai rata-rata (mean) 
sebesar 0.2809 dan standar deviasi sebesar 0.34207. Dan yang terakhir DER memiliki nilai antara 0.10-1.45 dengan nilai rata-rata (mean) sebesar 0.6306 dan standar deviasi sebesar 0.34965 .

Uji Asumsi Klasik yang dilakukan dalam penelitian ini adalah uji Normalitas, uji Multikolinearitas, uji Heteroskedastisitas, dan uji Autokorelasi. Hasil pengujian mendapati data penelitian ini memenuhi seluruh batasan asumsi klasik yang disyaratkan. Ini menunjukkan penelitian ini memenuhi syarat untuk dilakukan pengujian statistik inferensial.

Pengujian Hipotesis

Koefisien Determinasi $\left(\mathrm{R}^{2}\right)$ pada intinya mengukur seberapa jauh kemampuan variabel independen (ROA, pertumbuhan aset, pertumbuhan penjualan dan managerial ownership) dalam menerangkan variabel dependen (DER). Nilai koefisien determinasi yang ditunjukkan oleh $\mathrm{R}$ Square sebesar $(0,605)$ atau senilai $60,5 \%$ tersebut mengindikasi bahwa nilai dari DER pada perusahaan multinasional dapat dijelaskan oleh variasi dari variabel dependennya yaitu, ROA, pertumbuhan aset, pertumbuhan penjualan, dan managerial ownership, sedangkan 39,5\% sisanya dapat disebabkan oleh faktorfaktor lain diluar model penelitian. Selanjutnya nilai koefisien determinasi yang ditunjukkan oleh $\mathrm{R}$ Square sebesar $(0,678)$ atau senilai $67,8 \%$ tersebut mengindikasi bahwa nilai dari DER pada perusahaan multinasional dapat dijelaskan oleh variasi dari variabel dependennya yaitu, ROA, pertumbuhan aset, pertumbuhan penjualan, dan managerial ownership, sedangkan 32,2\% sisanya dapat disebabkan oleh faktor-faktor lain diluar model penelitian.

Uji hipotesis dilakukan dengan uji $F$ dan uji $t$, untuk uji statistik $F$ adalah uji untuk mengetahui apakah variabel independen secara bersama-sama atau simultan berpengaruh terhadap variabel dependen. Berdasarkan Uji F menunjukkan nilai $F$ hitung 7,664 dengan tingkat probabilitas 0,001. Karena tingkat probabilitas lebih kecil dari 0,05 atau 5\% maka model regresi dapat digunakan untuk memprediksi DER atau dapat dikatakan bahwa variabel ROA, pertumbuhan asset, pertumbuhan penjualan dan managerial ownership secara bersama-sama berpengaruh terhadap struktur modal (DER). Kemudiannilai $f$ hitung 10,515 dengan tingkat probabilitas 0,000. Karena tingkat probabilitas lebih kecil dari 0,05 atau 5\% maka model regresi dapat digunakan untuk memprediksi DER atau dapat dikatakan bahwa variabel ROA, pertumbuhan asset, pertumbuhan penjualan dan managerial ownership secara bersama-sama berpengaruh terhadap struktur modal (DER).

Uji $\mathrm{t}$ merupakan uji yang dilakukan untuk melihat seberapa jauh variabel independen secara individu mempengaruhi variabel dependen., sehingga persamaan regresi dari struktur modal (DER) sebagai berikut:

$$
\mathrm{DER}=0,809+0,568 \mathrm{ROA}+0,465 \mathrm{PA}+2,321 \mathrm{PP} \text { - 5,225 MO }
$$




\section{ROA terhadap DER}

Dari hasil perhitungan persamaan di atas, didapatkan nilai koefisien variabel ROA sebesar $(0,568)$. Dari hasil perhitungan uji secara parsial diperoleh nilai $t$ hitung sebesar $(3,460)$ dengan nilai signifikansi sebesar $(0,002)$. Karena nilai signifikansi lebih kecil dari 0,05 maka hipotesis 1 diterima berarti ada pengaruh signifikan antara variabel ROA dengan variabel DER.

\section{Pertumbuhan Aset terhadap DER}

Dari hasil perhitungan uji parsial diperoleh $t$ hitung sebesar $(0,984)$ dan nilai signifikasi sebesar (0,337). Karena nilai signifikasi lebih besar dari 5\%, maka hipotesis (H2) ditolak yang berarti tidak terdapat pengaruh signifikan antara variabel pertumbuhan aset dengan variabel DER. Brigham (1983) menyatakan bahwa aset perusahaan yang digunakan sesuai dengan aktivitas utama perusahaan cenderung akan menjamin pinjaman yang diterima, sehingga kreditor semakin terjaga keamanannya.

\section{Pertumbuhan Penjualan terhadap DER}

Dari hasil pengujian secara parsial diperoleh thitung sebesar 3,671 dan tingkat signifikan sebesar 0,002. Karena nilai signifikansi lebih kecil dari 0,05 maka diperoleh ada pengaruh yang signifikan dari variabel pertumbuhan penjualan terhadap DER. Hal ini berarti hipotesis 3 diterima. Hasil ini konsisten dengan penelitian yang dilakukan oleh Soukotta (2012).

\section{Managerial Ownership terhadap DER}

Kepemilikan saham manajemen atau managerial ownership, dari hasil estimasi regresi diperoleh nilai $t$ hitung sebesar $(-4,139)$ dengan tingkat signifikansi sebesar 0,001. Karena nilai signifikansi pengujian lebih kecil dari 0,05 maka diperoleh ada pengaruh yang signifikan dari variabel managerial ownership terhadap DER, hal ini berarti hipotesis 4 diterima.

$$
\text { DER = 0,650 - 0,067 ROA + 0,541 PA+ 0,818 PP - 0,682 MO }
$$

Dari persamaan regresi di atas dapat maka:

\section{ROA terhadap DER}

Dari hasil perhitungan uji secara parsial diperoleh nilai t hitung sebesar ($0,190)$ dengan nilai signifikansi sebesar $(0,851)$. Karena nilai signifikansi lebih besar dari 0,05 maka hipotesis 1 ditolak berarti tidak ada pengaruh signifikan antara variabel ROA dengan variabel DER.. 


\section{Pertumbuhan Aset terhadap DER}

Dari hasil perhitungan uji parsial diperoleh t hitung sebesar $(2,459)$ dan nilai signifikasi sebesar $(0,023)$. Karena nilai signifikasi lebih kecil dari 0,05, maka hipotesis (H2) diterima yang berarti terdapat pengaruh positif signifikan antara variabel pertumbuhan aset dengan variabel DER.

\section{Pertumbuhan Penjualan}

Dari hasil pengujian secara parsial diperoleh $t$ hitung sebesar $(1,847)$ dan tingkat signifikan sebesar $(0,010)$. Karena nilai signifikansi lebih kecil dari 0,05 maka diperoleh ada pengaruh yang positif signifkan dari variabel pertumbuhan penjualan terhadap DER. Hal ini berarti hipotesis 3 diterima.

\section{Managerial Ownership}

Kepemilikan saham manajemen atau managerial ownership, dari hasil estimasi regresi diperoleh nilai $t$ hitung sebesar $(-4,808)$ dengan tingkat signifikansi sebsesar $(0,000)$. Karena nilai signifikansi pengujian lebih kecil dari 0,05 maka diperoleh ada pengaruh yang signifikan dari variabel managerial ownership terhadap DER., hal ini berarti hipotesis 4 diterima. Hasil dari uji beda ditunjukkan dalam Tabel 3:

Tabel 3 Independent Sample T-Test ROA

\begin{tabular}{|c|c|c|c|c|}
\hline \multicolumn{2}{|c|}{} & \multicolumn{3}{|c|}{$\begin{array}{c}\text { t-test for Equality of } \\
\text { Means }\end{array}$} \\
\cline { 3 - 5 } \multicolumn{2}{|c|}{} & $\mathrm{T}$ & Df & $\begin{array}{c}\text { Sig. (2- } \\
\text { tailed) }\end{array}$ \\
\hline \multirow{2}{*}{ ROA } & $\begin{array}{l}\text { Equal variances not } \\
\text { assumed }\end{array}$ & -.766 & 31.142 & .450 \\
\cline { 2 - 5 } & & & & .448 \\
\hline
\end{tabular}

Perbedaan Return on Asset Perusahaan Multinasional dan Domestik

Berdasarkan hasil di atas diperoleh nilai sig. sebesar 0,448 pada equal variance assumed $\geq 0.05$, maka sesuai dengan dasar pengambilan keputusan, disimpulkan bahwa $\mathrm{H}_{0}$ diterima dan $\mathrm{H}_{1}$ ditolak yang berarti bahwa, tidak terdapat perbedaan ROA perusahaan multinasional dengan domestik. 
Perbedaan Pertumbuhan Aset Perusahaan Multinasional dan Domestik

Tabel 4 Independent Sample T-Test Pertumbuhan Aset

\begin{tabular}{|l|c|c|c|c|}
\hline \multicolumn{2}{|c|}{} & \multicolumn{3}{c|}{$\begin{array}{c}\text { t-test for Equality of } \\
\text { Means }\end{array}$} \\
\cline { 2 - 5 } \multicolumn{2}{|c|}{} & $\mathrm{t}$ & Df & $\begin{array}{c}\text { Sig. (2- } \\
\text { tailed) }\end{array}$ \\
\hline \multirow{2}{*}{$\begin{array}{l}\text { Pertumbuhan } \\
\text { Aset }\end{array}$} & $\begin{array}{l}\text { Equal variances } \\
\text { not assumed }\end{array}$ & -1.003 & 40.843 & .321 \\
\cline { 2 - 5 } & & & & .322 \\
\hline
\end{tabular}

Berdasarkan hasil uji di atas diperoleh nilai sig. (2-tailed) sebesar 0,321 pada equal variance assumed $\geq 0,05$, maka sesuai dengan dasar pengambilan keputusan, disimpulkan bahwa $\mathrm{H}_{0}$ diterima dan $\mathrm{H}_{1}$ ditolak yang berarti bahwa, tidak terdapat perbedaan pertumbuhan penjualan antara perusahaan multinasional dengan domestik.

Perbedaan Pertumbuhan Penjualan Perusahaan Multinasional dan Domestik

Tabel 5 Independent Sample T-Test Pertumbuhan Penjualan

\begin{tabular}{|l|l|c|c|c|}
\hline \multicolumn{2}{|c|}{} & \multicolumn{3}{|c|}{$\begin{array}{c}\text { t-test for Equality of } \\
\text { Means }\end{array}$} \\
\cline { 2 - 5 } \multicolumn{2}{|c|}{} & $\mathrm{T}$ & $\mathrm{df}$ & $\begin{array}{c}\text { Sig. (2- } \\
\text { tailed) }\end{array}$ \\
\hline \multirow{2}{*}{$\begin{array}{l}\text { Pertumbuhan } \\
\text { Penjualan }\end{array}$} & $\begin{array}{l}\text { Equal variances not } \\
\text { assumed }\end{array}$ & $\begin{array}{c}- \\
1.168\end{array}$ & 47.495 & .249 \\
\cline { 2 - 5 }
\end{tabular}

Berdasarkan hasil uji di atas diperoleh nilai sig. (2-tailed) sebesar 0,249 pada equal variance assumed $\geq 0,05$, maka sesuai dengan dasar pengambilan keputusan, disimpulkan bahwa $\mathrm{H}_{0}$ diterima dan $\mathrm{H}_{1}$ ditolak yang berarti bahwa, tidak terdapat perbedaan pertumbuhan penjualan antara perusahaan multinasional dengan domestik. 
Perbedaan Managerial Ownership Perusahaan Multinasional dan Domestik

Tabel 6 Independent Sample T-Test Managerial Ownership

\begin{tabular}{|c|c|c|c|c|}
\hline & \multicolumn{3}{|c|}{$\begin{array}{c}\text { t-test for Equality of } \\
\text { Means }\end{array}$} \\
\hline & & $\mathrm{T}$ & $\mathrm{df}$ & $\begin{array}{l}\text { Sig. }(2- \\
\text { tailed) }\end{array}$ \\
\hline \multirow{2}{*}{$\begin{array}{l}\text { Managerial } \\
\text { Ownership }\end{array}$} & & & & .002 \\
\hline & $\begin{array}{l}\text { Equal variances not } \\
\text { assumed }\end{array}$ & 3.300 & 25.018 & .003 \\
\hline
\end{tabular}

Berdasarkan hasil di atas diperoleh nilai sig. (2-tailed) sebesar 0,002 pada equal variance assumed $\leq 0,05$, maka sesuai dengan dasar pengambilan keputusan, disimpulkan bahwa $\mathrm{H}_{0}$ ditolak dan $\mathrm{H}_{1}$ diterima yang berarti bahwa, terdapat perbedaan Managerial Ownership antara perusahaan multinasional dengan domestik.

Perbedaan DER Perusahaan Multinasional dan Domestik

Tabel 7 Independent Sample T-Test DER

\begin{tabular}{|c|l|r|c|r|}
\hline \multicolumn{2}{|c|}{} & \multicolumn{3}{|c|}{$\begin{array}{c}\text { t-test for Equality of } \\
\text { Means }\end{array}$} \\
\cline { 3 - 5 } \multicolumn{2}{|c|}{} & $\mathrm{t}$ & Df & $\begin{array}{c}\text { Sig. (2- } \\
\text { tailed) }\end{array}$ \\
\hline \multirow{2}{*}{ DER } & & & & .001 \\
\cline { 2 - 5 } & $\begin{array}{l}\text { Equal variances not } \\
\text { assumed }\end{array}$ & -4.574 & 47.977 & .001 \\
\hline
\end{tabular}

Berdasarkan hasil di atas diperoleh nilai sig. (2-tailed) sebesar 0,001 pada equal variance assumed $\leq 0,05$, maka sesuai dengan dasar pengambilan keputusan, disimpulkan bahwa $\mathrm{H}_{0}$ ditolak dan $\mathrm{H}_{1}$ diterima yang berarti bahwa, terdapat perbedaan DER antara perusahaan multinasional dengan domestik.

\section{PEMBAHASAN}

\section{Return on Asset terhadap DER}

Hasil ini menunjukkan bahwa dengan meningkatnya ROA akan meningkatkan daya Tarik pihak eksternal (investor dan kreditor), dan jika kreditor semakin tertarik untuk menanamkan dananya ke dalam perusahaan, sangat dimungkinkan DER juga semakin meningkat. Hasil penelitian ini konsisten dengan penelitian yang dilakukan oleh Putra (2006; Yuliani 2017) yang juga menunjukkan hasil bahwa ROA berpengaruh positif terhadap DER. 
Sedangkan pada perusahaan domestik menunjukkan bahwa ROA tidak berpengaruh terhadap DER. Hasil penelitian ini mendukung packing order theory, yang menyatakan bahwa perusahaan domestik yang ada di Indonesia merupakan perusahaan yang memiliki profit dalam jumlah yang besar, sehingga perusahaan lebih memilih menggunakan internal financing melalui laba ditahan untuk mendanai kegiatan operasinya. Namun, tinggi rendahnya profit tidak mampu menjamin besarnya jumlah hutang yang akan digunakan oleh perusahaan domestik. Ketidakstabilan profit ini menjadikan perusahaan domestik kurang memperhatikan jumlah hutang dalam struktur modalnya, sehingga ROA tidak memiliki pengaruh terhadap DER. Hasil penelitian ini sejalan dengan penelitian yang dilakukan oleh Sinthayani (2015) dan Hermuningsih (2016).

Hasil ini konsisten dengan penelitian yang dilakukan oleh Putra (2006) yang menunjukkan hasil bahwa pertumbuhan aset tidak signifikan mempengaruhi DER. Brigham (1983) menyatakan bahwa aset perusahaan yang digunakan sesuai dengan aktivitas utama perusahaan cenderung akan menjamin pinjaman yang diterima, sehingga kreditor semakin terjaga keamanannya. Pertumbuhan aset tidak berpengaruh terhadap DER karena peningkatan aset perusahaan tidak menarik minat investor untuk menanamkan dananya karena investor lebih melihat tingkat pengembaliannya.

Hasil penelitian ini mengindikasi bahwa semakin besar aset yang dimiliki perusahaan diharapkan semakin besar hasil operasional yang dihasilkan oleh perusahaan. Peningkatan aset yang diikuti peningkatan hasil operasi akan semakin menambah kepercayaan dari pihak luar terhadap perusahaan. Dengan meningkatkan kepercayaan dari pihak luar (kreditor) terhadap perusahaan, maka proporsi hutang semakin lebih besar daripada modal sendiri. Hal ini sejalan dengan penelitian yang dilakukan oleh (Dwiyati 2011).

\section{Pertumbuhan penjualan terhadap DER}

Hasil ini konsisten dengan penelitian yang dilakukan oleh Soukotta (2012). Bagi perusahaan dengan tingkat pertumbuhan yang tinggi, kecenderungan penggunaan hutang lebih besar dibandingkan dengan tingkat pertumbuhan rendah Hanafi (2016). Sedangkan menurut Brigham, Eugene F. dan Houston (2010), perusahaan dengan penjualan yang relatif stabil dapat lebih aman memperoleh lebih banyak pinjaman dan menanggung beban tetap yang lebih tinggi dibandingkan dengan perusahaan yang penjualannya tidak stabil. Hal ini disebabkan karena kebutuhan dana yang digunakan untuk pembiayaan pertumbuhan penjualan semakin besar. Perusahaan yang tumbuh dengan pesat harus lebih banyak mengandalkan modal eksternal. 


\section{Managerial Ownership terhadap DER}

Hasil ini sesuai dengan penelitian yang dilakukan oleh Putra (2006) yang menunjukkan pengaruh yang negatif antara saham yang dimiliki oleh manajer terhadap DER. Hasil penelitian ini mengindikasi sebuah perusahaan dimana manajer memiliki saham yang besar muncul kecenderungan manajer tersebut akan mengurangi biaya keagenan hutang. Teori keagenan (agency Theory) juga menyatakan bahwa konflik kepentingan antara manajemen dengan pemegang saham dapat diminimumkan dengan suatu mekanisme pengawasan yang dapat mensejajarkan kepentingan. Namun munculnya mekanisme pengawasan tersebut akan menimbulkan biaya yang disebut agency cost. Biaya keagenan (agency cost) dapat dikurangi dengan meningkatkan kepemilikan manajemen di dalam perusahaan (insider shareholder) sehingga manajemen merasa ikut memiliki dan merasakan langsung dari hasil keputusan yang diambil. Hasil ini menunjukkan bahwa tidak terdapat perbedaan ROA, pertumbuhan aset dan pertumbuhan penjualan antara perusahaan multinasional dengan domestik sedangkan terdapat perbedaan managerial ownership dan struktur modal antara perusahaan multinasional dengan domestik.

\section{PENELITIAN LANJUTAN}

Implikasi penelitian ini adalah ketika investor berinvestasi pada perusahaan multinasional maka sedapat mungkin berhati-hati ketika terjadi peningkatan profitabilitas karena akan diikuti peningkatan rasio hutang yang merupakan risiko perusahaan. Sedangkan untuk ke dua kelompok perusahaan sedapat mungkin berhati hati ketika terjadi peningkatan pertumbuhan penjualan karena akan berisiko meningkatkan rasio hutang. Sehingga jalan yang baik untuk ditempuh adalah mengurangi pembelian produk dalam bentuk kredit pada pemasok.

Keterbatasan penelitian ini adalah model rasio hutang yang dibentuk hanya sampai pada ROA, Pertumbuhan Asset, Pertumbuhan penjualan dan managerial ownership utamanya pada perusahaan multinasional dan domestik. Sehingga untuk pengembangan ke depan sebaiknya menggunakan variabel lain misalnya keputusan investasi dan kebijakan dividen sehingga dapat lebih menyempurnakan model rasio hutang pada perusahaan yang terdaftar pada Bursa Efek Indonesia.

\section{DAFTAR PUSTAKA}

Andriasari, Widi Savitri, Miyasto, and Wisnu Mawardi. 2014. “Analisis Pengaruh Kebijakan Hutang, Pertumbuhan Penjualan (Growth Sales) Dan Return on Asset (ROA) Terhadap Return Saham Dengan Return on Equity (ROE) Sebagai Variabel Intervening." Jurnal Bisnis Strategi. 
Ar, Mulyadi. 2013. “Pengaruh Lingkungan Budaya Pendidikan Terhadap Intensitas Peran Akuntansi Manajemen Pada Perguruan Tinggi Di Provinsi Nanggroe Aceh Darussalam." Jurnal Akuntansi Muhammadiyah.

Avramov, Doron, Tarun Chordia, Gergana Jostova, and Alexander Philipov. 2013. "Anomalies and Financial Distress." Journal of Financial Economics. https:// doi.org/10.1016/j.jfineco.2012.10.005.

Awaluddin, M. 2006. Analisis Pengaruh Financial Leverage Terhadap Risiko dan Return Saham Sebelum dan Sesudah Masa Krisis Moneter. " Jurnal Jupiter" Vol IV No.1 Tahun 2006

Awaluddin, M. 2009. Research on Key Factors in Determining Value of Firms for Listed Manufacturing Firms at Indonesian Stock Exchange, Unpublished Dissertation Post Graduate Program Hasanuddin University

Awaluddin, M. (2016). Pengaruh Modal Kerja Dan Perputaran Persediaan Terhadap Profitabilitas Melalui Likuiditas (Studi Kasus Pada Perusahaan Farmasi Yang Terdaftar Di BEI Periode 2010-2014). Jurnal Minds: Manajemen Ide dan Inspirasi, 3(2).

Bergh, Donald D., Brian L. Connelly, David J. Ketchen, and Lu M. Shannon. 2014. "Signalling Theory and Equilibrium in Strategic Management Research: An Assessment and a Research Agenda." Journal of Management Studies 51 (8): 1334-60. https://doi.org/10.1111/joms.12097.

Brigham, Eugene F. \& Houston, Joel F. 2010. Dasar-Dasar Manajemen Keuangan. Salemba Empat. https:/ / doi.org/10.1145/2505515.2507827.

Detiana, Tita. 2011. "Pengaruh Rasio Keuangan, Pertumbuhan Penjualan Dan Dividen Terhadap Harga Saham." Jurnal Bisnis Dan Akuntansi.

Dwiyati, Winda Ayu. 2011. "Analisis Pengaruh Return on Asset, Pertumbuhan Asset, Pertumbuhan Penjualan, Managerial Ownership Dan Arus Kas Operasi Terhadap Struktur Modal/Debt to Equity Ratio." Fakultas Ekonomi Universitas Diponegoro Semarang.

Hanafi, Mamduh. 2016. Manajemen Keuangan. Yogyakarta: BPFE-Yogyakarta.

Handayan, i Anita. 2016. "Struktur Modal Perusahaan Multinasional Dan Perusahaan Domestik Pada Indeks LQ 45." Sumatera: Fakultas Ekonomi Universitas Muhammadiyah Gresik.

Hermuningsih, Sri. 2016. "Pengaruh Profitabilitas, Size Terhadap Nilai Perusahaan Dengan Sruktur Modal Sebagai Variabel Intervening." Jurnal Siasat Bisnis. https://doi.org/10.20885/jsb.vol16.iss2.art8.

Husnan, Suad, and Pudjiastuti Enni. 2015. Dasar-Dasar Manajemen Keuangan. Yogyakarta: UPP STIM YKPN.

Jensen, Michael C., and William H. Meckling. 1976. "Theory of the Firm: Managerial Behavior, Agency Costs, and Ownership Structure." Journal of Financial Economics 3 (4): 305-60.

Linder, Stefan, and Nicolai J. Foss. 2015. "Agency Theory." In International Encyclopedia of the Social $\mathcal{E}$ Behavioral Sciences: Second Edition. https://doi.org/10.1016/B978-0-08-097086-8.73038-8. 
Marfuatun, Siti, And Iin Indarti. 2012. “Pengaruh Earning Per Share, Debt to Equity Ratio, Dan Return On Equity Terhadap Harga Saham Perusahaan LQ-45 Di Bursa Efek Indonesia." Aset.

Maryanti, Eny. 2016. "Analisis Profitabilitas, Pertumbuhan Perusahaan, Pertumbuhan Penjualan Dan Struktur Aktiva Terhadap Struktur Modal Pada Perusahaan Sektor Industri Barang Konsumsi Yang Terdaftar Di Bursa Efek Indonesia (Studi Empiris Pada Perusahaan Manufaktur Yang Terdaf." Riset Akuntansi Dan Keuangan Indonesia. https://doi.org/10.23917/reaksi.v1i2.2730.

Metha Arieska, and Barbara Gunawan. 2011. "Pengaruh Aliran Kas Bebas Dan Keputusan Pendanaan Terhadap Nilai Pemegang Saham Dengan Set Kesempatan Investasi Dan Dividen Sebagai Variabel Moderasi." Jurnal Akuntansi Dan Keuangan.

Morris, Richard D. 1987. "Signalling, Agency Theory and Accounting Policy Choice." Accounting and Business Research. https:// doi.org/10.1080/00014788.1987.9729347.

Myers, Stewart C., and Nicholas S. Majluf. 1984. "Corporate Financing and Investment Decisions When Firms Have Information That Investors Do Not Have." Journal of Financial Economics. https://doi.org/10.1016/0304405X(84)90023-0.

Najmuddin. 2011. Manajemen Keuangan Dan Aktualisasi Syar'iyyah Modern. Yogyakarta: C.V Andi Offset.

Putra, Bayu Septadona. 2006. “Analisis Pengaruh Struktur Kepemilikan, Rasio Pertumbuhan Dan Return on Asset Terhadap Kebijakan Pendanaan (Perbandingan Pada Perusahaan PMA Dan PMDN Yang Listed Di BEJ Periode 2002-2004)." Universitas Diponegoro.

Putri, Endah Damay. 2017. "Pengaruh Growth Opportunity, Struktur Asset Dan Profitabilitas Terhadap Struktur Modal." Simki-Economic.

Sari, D. V., and A.M. Haryanto. 2013. "Pengaruh Profitabilitas, Pertumbuhan Aset, Ukuran Perusahaan, Struktur Aktiva Dan Likuiditas Terhadap Struktur Modal Pada Perusahaan Manufaktur Di Bursa Efek Indonesia Tahun 2008 - 2010." Diponegoro Journal of Management.

Sinthayani, Dian dan Ida Bagus Panji Sedana. 2015. “Determinan Struktur Modal (Studi Perbandingan Pada Manufacture Multinational Corporation Dan Domestic Corporation Di BEI)." Fakultas Ekonomi Dan Bisnis Universitas Udayana.

Soukotta, Agnes. 2012. “Analisis Faktor-Faktor Yang Mempengaruhi Struktur Modal (Studi Perbandingan Pada Manufactur Multinasional Company Dan Manufacture Domestic Corporation Di Bursa Efek Indonesia." Fakultas Ekonomi Dan Bisnis Universitas Diponegoro Semarang.

Yuliani, Yuliani Yuliani. 2017. “Analisis Struktur Modal Perusahaan Industri Makanan Dan Minuman Di Bursa Efek Indonesia." Ekspektra: Jurnal Bisnis Dan Manajemen. https:// doi.org/10.25139/ekt.v0i0.135. 